\title{
Friedrich Nietzsche's politics of genius and its challenge for liberal-democratic Europe
}

No matter how we analyse the works of the German philosopher, it is not possible to find explicit and sustained political thought in it. Perhaps this is due to the fact that Friedrich Nietzsche himself does not divide his output into particular fields. Even so, from the whole of his works emerges a theoretical outline of a political system, a system which is neither a doctrine nor a peculiar paradigm. As in all of Nietzsche's philosophy, his political suggestions grow organically from the stem, which is $\operatorname{man}^{1}$. As Karl Jaspers noticed, Nietzsche outlines his "great politics" ${ }^{2}$ as part of his search for an authentic human being, that is, from his care for that human being's future, development and dignity. This politics does not provide specific solutions for specific problems. It is far from supplying formulas for finding one's place in the great mechanism of social behaviours. It is full of contradictions. It is not as constructive as Hegel's politics or as practical as Machiavelli's. It does not delve into specific actions like the systems constructed by Rousseau, Locke, or Hobbes. It merely specifies the general conditions allowing man to take the next step in his evolution. That evolution is not about the survival of the greatest number of individuals, but rather the greatness of the few ${ }^{3}$. It is

1 "We [philosophers] have no right to isolated acts of any kind: we may not make isolated errors or hit upon isolated truths. Rather do our ideas, our values, our yeas and nays, our ifs and buts, grow out of us with the necessity with which a tree bears fruit - related and each with an affinity to each, and evidence of one will, one health, one soil, one sun". See F. Nietzsche, On the genealogy of Morals, transl. by W. A. Kaufmann, Vintage Books, New York 1989, Preface, p. 2.

2 See K. Jaspers, Nietzsche. Wprowadzenie do rozumienia jego filozofii, transl. by D. Stroińska, Wydawnitwo KR, Warszawa 1997, p. 199.

3 "A nation is a detour of nature to arrive at six or seven great men and then to get around them". See F. Nietzsche, Pisma pozostałe 1862-1875, transl. by B. Baran, 
about exceptional individuals who do not need institutions - those artificial products of civilisation - and it is especially not about those liberal, democratic, and republican institutions so characteristic of this modern age. It is not about the crowds of the average - those masses who have stopped halfway on the road to perfection. It is not for those who are satisfied with the previous achievements of the human species and who do not hope for further intellectual and moral development.

While Nietzsche's publications say very little on the existing institutions of human political activities, such statements can be found and, should we try to outline his political philosophy, they should be presented $^{4}$. Despite their many tensions with each other, the main direction of his philosophy remains unaffected by those internal conflicts. The changes do not relate to a specific end, but only the means to achieve it, for throughout his entire life Nietzsche was a consistent enemy of "the people", freedom, and democracy ${ }^{5}$.

\section{The state and the nation}

During a time of crisis of European culture, a form of the state emerged that was unacceptable for Friedrich Nietzsche. The state was acceptable as long as it was a wise institution capable of defending individuals against each other. According to the philosopher, this is the primary and the most proper function of the state. However, it has been disintegrated in the attempt to increasingly refine this form of organisation of the so-

Wydawnictwo inter esse, Kraków 1993, p. 280. Idem, Beyond Good and Evil, transl. by P. Pieniążek, Wydawnictwo Zielona Sowa, Kraków 2005, p. 79. Nietzsche perceived humanity as a raw material from which can only a few great individuals emerge. The entirety of Nietzsche's philosophy will be influenced by specific ethics, based on which he created his works. Therefore, he suggested that, if necessary, it was better to sacrifice the whole nation to keep a single outstanding individual alive.

4 More on this topic can be found in P. Zientkowski, Teoria praw człowieka $i$ jej krytyka w filozofii Fryderyka Nietzschego, Chojnice 2013, p. 149-157.

5 However, what democracy is for Nietzsche to a large extent remains an open matter. It is not one of prevailing political doctrines or theories. It is not the will of the majority, since according the philosopher it gets its meaning solely because of the form which defines it. An example is the general right to vote where the will of the majority decides what is good for everyone. For the author of Zarathustra, democracy is development in two stages. The pre-Socratic version of Greek culture, which the philosopher valued the most, met its demise through the abuse of power by Rome and then subsequent inability to control the spread of Christianity. The victor turned out to be the weak Christian religion promoting unhealthy equality. The second stage of the road to democracy became the natural process of atrophy of Christian faith, which evolved into socialism and new democracy. More information on this topic can be found in A. Szahaj, M. Jakubowski, Filozofa polityki, Wydawnictwo Naukowe PWN, Warszawa 2005, p. 84-87. 
ciety. "Our times - he used to say - are the times of an imperfect state, a semi-barbaric society which still has a chance to live in a poetic unreality and which loses its greatest values while pursuing total perfection" ${ }^{\prime \prime}$. Nietzsche unleashed his bitterness with waves of criticism of Bismarckian Germany and, above all, of Hegel's idealising the state, according to which only the state can provide the proper conditions for and the embodiment of human development. Nietzsche did not negate the need of existence of the institution of the state as such. Seeking political paragons in the pre-Socratic era, Nietzsche perceived the state as a unique institutional power capable of shaping a true human being, nation and culture $^{7}$. Without it, there would be no stability in relations between people, and the society could not go beyond the limits of the basic organisational form of the family. Without it there would be no wars, so necessary to provide a vent for social urges. Finally, without it culture could not develop, if it were necessary to re-establish its foundations over and over again. According to Nietzsche, culture exists solely because of the state, which encompasses all social processes like a steel clamp.

However, the same state poses a grave threat to mankind. It is this danger he had in mind when he wrote in The Dawn of Day: "The least possible state" ${ }^{\prime \prime}$. Therefore, he warns us, to keep available any means necessary to pursue high and noble goals, and to prevent the state from becoming a nullifying power severing itself from the creative attitude of man, which would move it away from the most important task it has been entrusted with - "the birth of a genius" .

Another danger Nietzsche warns against is putting the state above everything else, treating it like an objective rather than as one means of reaching it. It is necessary to reject the new idol and not allow it to subdue anyone. According to the philosopher, the state is not a value

6 See F. Nietzsche, Human, All Too Human, transl. by K. Drzewiecki, Wydawnictwo Zielona Sowa, Kraków 2003, p. 149-150.

7 See K. Jaspers, Nietzsche, p. 203.

${ }^{8}$ F. Nietzsche, The Dawn of Day, transl. by L. M. Kalinowski, Wydawnictwo Zielona Sowa, Kraków 2006, p. 121.

9 In the notion of a Nietzschean genius we can see the complete figure of the superman. However, in the light of the philosophy of the author of Zarathustra a greater man and thus a genius is not only a complete product - the übermensch, whom we can call a crepuscular man, as Bogdan Baran did. See B. Baran, Postnietzsche. Reaktywacja, Wydawnictwo inter esse, Kraków 2003, p. 49-61. After all, he is also "a player who missed his throw". This is suggested by Nietzsche himself when he distinguishes historical figures with the label of genius: Borgia is called, in the Twilight of the Idols, "a certain superman"; or Napoleon, who in the On the Genealogy of Morality is described as "the synthesis of a non-human and an superman". More information on this topic can be found in B. Banasiak, Nietzscheański Nadczłowiek-dylematy $i$ aporie, in: Wokót Nietzschego, eds. B. Banasiak, P. Pieniążek, Wydawnictwo Adam Marszałek, Torun 2009, p. 159-177. 
in itself but only a helpful tool in the creation of a nation, a culture, or a creative individual. Otherwise, it becomes an enemy and leads to the "death of nations". Nietzsche phrases it this way:

He who regards his life as no more than a point in the evolution of a race or of a state or of a science and thus regards himself as belonging wholly to the history of becoming has not understood the lesson set him by existence and will have to learn it all over again. This eternal becoming is a lying puppet-play in beholding which man forgets himself, the actual distraction, which disperses the individual to the four winds, the endless stupid game which the great child, time, plays before us and with us. That heroism of truthfulness consists in one day ceasing to be the toy it plays with ${ }^{10}$.

The ideal solution becomes the achievement of a model of behaviour in which it is the individual who will be able to sacrifice his own state to live according to its ideals. He describes such an attitude as the individual's greatest achievement and deems it to be a value future generations should inherit.

Nietzsche was aware that the beginning of the state is power - the very power which seeks to obliterate man, turn the masses into slaves, but without which no human society or creative being can exist. It is the source of and, at the same time, a constant feature of the institution of the state $^{11}$. As a philosopher, but also as a philologist and expert on Plato, he attributed considerable importance to his concept of an ideal state. In that ideal state, everything is in its rightful place, since some of its citizens constantly practise obedience while others give commands ${ }^{12}$. In spite of the fact that in Plato's concept the state is led by philosopher kings, and while Nietzsche himself believed that no political or economic situation deserves being tackled by the most gifted individuals ${ }^{13}$, both Nietzsche and Plato have the same goal. For Plato, the state is nothing else than an expanded image of man ${ }^{14}$. Furthermore, Plato's vision of the

10 F. Nietzsche, Untimely Meditations, transl. by L. Staff, Wydawnictwo Zielona Sowa, Kraków 2003, p. 150.

11 See K. Jaspers, Nietzsche, p. 203.

12 “The goal of Nietzsche's politics is the enhancement or heightening (Erhöhung) of the type human, an enhancement achieved by individual souls. Aristocratic society and the slavery it presupposes are instrumental necessities, preconditions of the true aim, the aristocratic individual. The politics of the philosopher Nietzsche, like the politics of the philosopher Plato, serves the interest of philosophy, but these are highest interest of humanity". See L. Lampert, Nietzsche's Task: An Interpretation of Beyond Good and Evil, Yale University Press, New Haven/London 2001, p. 264.

13 F. Nietzsche, The Dawn of Day, p. 121.

14 G. Reale, A History of Ancient Philosophy, Vol. 2, transl. by E. I. Zieliński, TN KUL, Lublin 2001, p. 289. 
state attaches tremendous importance to finding and raising such members of the society in whom the rational part of their soul dominates the two others - will and passion. Using proper and time-consuming upbringing and education, this "material" is transformed into outstanding individuals ${ }^{15}$. Thus geniuses are created.

The same task is set for the state by Friedrich Nietzsche, as evidenced by his constantly-repeated point that the proper purpose of the state is the creation and preparation of the genius ${ }^{16}$. The genius is an individual whom the state serves, but who is also grateful because he remembers that because of the state's assistance and protection he has reached his status $^{17}$. In a genius Nietzsche sees someone who is able to distance himself from the reality in which he was destined to live in and who, from his new perspective, can pass legislative judgments - becoming "the judge and the measurer of things"18. For Nietzsche such geniuses are, first of all, Goethe and Schopenhauer. (The influence of Schopenhauer especially led Nietzsche to conclude that the purpose of the state is to ensure public order and defence against foreign enemies ${ }^{19}$.)

The notion of a nation in Nietzsche's works is treated often almost interchangeably with the notions a mass or a mob. The nation is a mass, but a mass is merely a collection of feeble copies of outstanding individuals. As such, in the apt hands of "the great" the nation could become a perfect tool for achieving goals. The mass is also the resistance against great individuals ${ }^{20}$. Through the constant urge of "the will to power," the mass provides a specific tension which stimulates a higher degree of freedom in them.

However, the philosopher held the nation in higher regard than the state. Nietzsche absolutely separated both notions, making them inde-

15 This fact was pointed out by Stanisław Łojek. See S. Łojek, Obrona Nietzschego. Rzecz o odpowiedzialności, Wydawnictwo Antyk, Kęty 2002, p. 72.

16 See. L. Kusak, Fryderyk Nietzsche. W poszukiwaniu utraconego ideatu, Księgarnia Akademicka, Kraków 1995, s. 28.

17 Ibidem, p. 32. This puts Nietzsche in contradiction to the Socrates of Plato's Crito. There Socrates suggests that, because of one's debts to the state for its assistance, one is always its child or slave (doulos). See Plato, Crito 50e-51b.

18 "Genuine philosophers, however, are commanders and legislators: they say, 'thus it shall be!... Their 'knowing' is creating, their creating is a legislation, their will to truth is - will to power". See F. Nietzsche, Beyond Good and Evil. Prelude to a Philosophy of the Future, transl. by W. A. Kaufmann, Vintage Books, New York 1966, s. 211.

19 See. A. Schopenhauer, Parerga and Paralipomena Parerga i Paralipomena, transl. J. Garewicz, t. 2, Wydawnictwo Antyk, Kęty 2006, p. 220.

20 An interesting view of the category of resistance in Nietzsche's works can be found in papers by Adam Dubik. See A. Dubik, Filozofia i opór, Wydawnictwo UMK, Toruń 2003, p. 57-89. Likewise, M. Janik, Nietzscheańska droga oporu - w stronę ontologii politycznej, in: Wokót Nietzschego, p. 289-300. 
pendent ${ }^{21}$ and treating the impact of the state on the nation as a misunderstanding. In his opinion, political prosperity at the cost of depletion and reduction in the efficiency of the spirit in the nation was not worth it. For example, the author of the Twilight of the Idols lamented the tragic mistake that was drawing the best sons of the nation away from their activities and duties to make them something else - soldiers. The terrible mistake was to sacrifice many of the most outstanding talents on the "altar of homeland" to satisfy "national ambitions", when it is not politics but other vital fields of cultural activities that require their courage and genius ${ }^{22}$. However, such an action is not possible without the approval of the majority, that mass of slaves, who have chosen a safer fate and who are unaware of the price they pay - becoming superfluous human beings. As the author of On the Genealogy of Morality says, "Many too many are born: for the superfluous ones was the state devised"23. He continues: "There, where the state ceaseth - there only commenceth the man who is not superfluous: there commenceth the song of the necessary ones, the single and irreplaceable melody. There, where the state ceaseth - pray look thither, my brethren! Do ye not see it, the rainbow and the bridges of the Superman?"24

Friedrich Nietzsche himself chose to become a stateless person. Either deliberately or as a result of negligence, from 17 April 1869 to the end of his life he was not officially a citizen of any state ${ }^{25}$.

\section{The individual and the masses}

The destructive, omnipresent pressure of the mass, those superfluous ones, causes irreversible changes in a human being. Those who still perceive themselves as individuals and form a nation when standing together, become a small minority among all those enslaved by the spirit. Many desire only welfare and, like a herd, want all to be equal, little and

21 "There, where there is still a people, there the state is not understood, but hated as the evil eye and as sin against laws and customs". See F. Nietzsche, Thus Spoke Zarathustra, transl. by W. Berent, Wydawnictwo Antyk, Kęty 2004, p. 37.

22 See. F. Nietzsche, Human, All Too Human, p. 242.

23 Idem, Thus Spoke Zarathustra, p. 37.

24 Ibidem, p. 38.

25 As a Prussian citizen he could have been drafted into the military at any moment. Fearing this, the authorities of the University of Basel, when offering Nietzsche the chair of philology, also suggested that he change his citizenship to Swiss. Nietzsche submitted the required documents, and on 17 April 1869 he ceased to be a Prussian citizen. However, he never fulfilled the conditions necessary to become a Swiss citizen, and thereby from the age of 25 until his death he remained a stateless person. See R. J. Hollingdale, Nietzsche, transl. Wł. Jeżewski, PIW, Warszawa 2001, p. 53-54. 
insignificant like themselves. However, they form the "majority" and they dangerously push the world towards the abyss of meaningless existence in the name of this majority. Their existence is as those of prisoners and slaves. The creators of their morality preach how to live, which protects and justifies their conduct and lifestyle. When they look upon a genuine individual, they do not see a genius whose means of conception they are, after all - rather they see a criminal in him - a defiant, vain immoralist placing himself above good and evil. Therefore, the author of Antichrist urged the greater man to declare war on the mass of average ones who have closed ranks to take control of the world. As Nietzsche says, "...no consideration for numbers: the masses, the miserable and the unfortunate concern me little - but the first and the most splendid types and that out of consideration for the ill-bred they do not come off badly"26.

According to Nietzsche, the whole problem with the herd instinct consists in the fact that the masses hold the middle ground, and mediocrity is their most valuable and precious value. Such insipid Aristotelic aurea mediocritas is perceived as a standard by the mob and as a formula for mediocrity. In the herd, being an exception - though being an answer to the Biblical "I wish you were either cold or hot" - is viewed as an offence. This is because the herd experiences an exception in the hierarchy, both above and below itself. At that time it is trying to take advantage of the situation providing as much benefit for itself as possible, trampling the little people and forcing the more powerful to assume "the role of guardians, herdsmen, watchmen - [...] its first servants: it has therewith transformed a danger into something useful" 27 .

The ideals of the masses reach their summits only if they provide the greatest addition of value to the society. This connects us to Nietzsche's sympathy to aristocratism, which was the target of the resistance of the herd. By looking down upon the masses scornfully and condescendingly, stronger individuals are able to flourish and become even stronger, and by separating themselves from the herd they can protect their rights. The philosopher points out that the more rights the genius gives away, by which he becomes more and more equal, the more he is subject to the dominance of the most numerous group and the average ones. Therefore, the power of the herd instinct is a tool to establish something inherently absurd and so different from the instinct of the aristocratic community, in which the meaning of the sum is dependent on the individuals. The herd is supposed to be like the genuine individuals, not the other way round!

26 F. Nietzsche, Pisma pozostałe, p. 337.

27 Ibidem, p. 382. 
A subtle difference causes Nietzsche's reluctance toward the Darwinian theory of the origin of species. Nietzsche openly claims, "Our entire sociology simply does not know any other instinct than that of the herd, i.e., that of the sum of zeroes - where every zero has equal rights, where it is virtuous to be zero..."28. The author of The Will to Power is aware that masses have always played an important, contributory role in the history of nations. This has happened despite the fact that all civilisations have risen and flourished primarily because of the power of the sparse group of aristocracy. Their demises have always been caused solely by the destructive power of the mob that unwittingly and brutally overthrows the old order along with a change in the moral forces on which they were based ${ }^{29}$. The ethics of the masses requires the individual to adjust its behaviours to the expectations of the herd. As Ernst Barker argues, truthfulness is praised because it allows the herd to know what it is supposed to expect. Lying is condemned because it leaves the herd in ignorance. The rhetorical questions the author of the Zarathustra asks us at this point are: Should the benefit of the masses be the final criterion of human action? What does really show a human being the authentic way to full realization? Reason, the conscience, or possibly the herd's desires? ${ }^{30}$

The morality of the herd denies the existence of free will and negates the existence of conscience. After all, free will is nothing else than imposing the principle of responsibility on the mankind. Meanwhile, conscience is not the source of assessments of moral values. The mob, appealing to its own emotions, forms values by satisfying its senses. Like a sensuous artist enjoying his work, the herd becomes the final tribunal in assessment of the values of deeds being solely guided by the feeling of satisfaction. In this way the community assigns moral value to deeds and intentions according to their benefits to itself. Once such a morality is established, its instructions will be imitated. It does not matter that such a morality, which has lasted for centuries and is followed by most people, is regarded true among this crowd of "slaves", for whom it is sufficient that they live. The slave morality of the herd would be false if it were imposed upon a genius, who, apart from the Darwinian desire for existence, seeks power. This individual thus follows the morality of power. The morality of the herd is good for slaves, who demand truth and mercy for themselves and people similar to them. Those two are the

28 Ibid., p. 407.

29 See G. Le Bon, The Crowd: A Study of the Popular Mind, transl. by B. Kaprocki, Wydawnictwo Antyk, Kęty 2004, p. 12.

${ }_{30}$ An interesting view on this topic can be found in S. Łojek, Hegel and Nietzsche wobec problemu polityczności, Wydawnictwo UWr, Wrocław 2002, p. 134. 
conditions of existence, and since slaves do not expect anything more, they are engraved in his nature ${ }^{31}$.

Such a double morality, appropriate for different human classes, can be already found in Plato's works ${ }^{32}$ and can be traced in its concealed form across the centuries to our own time. However, the prevalent view is still the commonly acknowledged morality of the herd, which is, as Barker ${ }^{33}$ points out - the morality of democracy, socialism, or Christianity. All three of those doctrines stand against the natural hierarchy that gives the stronger control over the weak, and all three are the constant targets of the Nietzschean attack. The likely rule of the masses, i.e., the institutional democracy, will allow common mediocrity to seize power, perhaps as a quarantine against the old plague of tyranny ${ }^{34}$. However, as Mariusz Moryń argues, it trends, albeit unwittingly, towards results opposite to the intended one: by making citizens similar to one another it paves the way for the reign of future tyrants ${ }^{35}$. The Nietzschean hatred for democracy is clearly influenced by Plato's philosophy. Just like the author of Gorgias, Nietzsche believes that the common citizens are incompetent, poorly informed, and easy to manipulate, so the rule of a numerous group that demands equality for all is bound to cause tragic consequences.

According to Nietzsche, the only and the right response to the creeping degradation of mankind is promotion of the superman. Therefore, he urged us to commence a long-lasting and resource-consuming process of breeding outstanding individuals - and this pursuit should become a new religion for all of humankind. He included instructions about how it should be done in Human, All Too Human, where he demanded that people live in harsh austerity, taking care of their intellectual and physical development. Mirosław Żelazny rightly argues that the Nietzschean philosophy does not proclaim any supernatural features of the genius, since every geniality is the effect of entirely natural hard work, courage, and the self-imposed overcoming one's own weaknesses ${ }^{36}$. Nietzsche himself recommended patience and moderation, because he was aware that many generations to come would not see the superman yet.

31 See. E. Barker, Nietzsche and Treitschke: the Worship of Power in Modern Germany, transl. by W. Kierat, Wydawnictwo M. Arcta, Warszawa 1915, p. 7-10.

32 See Plato, Gorgias, transl. by P. Siwek, PWN, Warszawa 1991, p. 39-52.

33 E. Barker, Nietzsche and Treitschke: the Worship of Power in Modern Germany, transl. by W. Kierat, Wydawnictwo M. Arcta, Warszawa 1915, p. 11.

34 F. Nietzsche, The Wanderer and His Shadow, transl. by K. Drzewiecki, Wydawnictwo Zielona Sowa, Kraków 2003, p. 238.

35 M. Moryń, Wola mocy i myśl. spotkania z filozofia Fryderyka Nietzschego, Dom Wydawniczy „Rebis”, Poznań 1997, p. 79.

36 See M. Żelazny, Nietzsche „Ten wielki wzgardziciel”, Wydawnictwo UMK, Toruń 2007, s. 197. 
In his works the author of Zarathustra outlined the image of politics in a distorting mirror. In a place where everything for the good of everyone should be clear, pure and simple, it appears to be a caricature of fairness. It is a sad truth, but it is the condition of achieving the objective. This is because every political performance, no matter whether that of a single person, a party or the whole nation, is effective only when it is a show put on by a wolf in sheep's clothing. However, these are not the worst aspects of great politics. Spectacles take place that are truly more dreadful and which are constantly repeated, forcing every brave, hardworking, wise member of the nation, including those who seek political fame, to submit to the spectacle's demands. At the same time, he must cease to invest his efforts in the cause which he had vocation for like he used to do before. Every day his energy is absorbed by the repeating issues and concerns of the common good. Every citizen loses part of the capital of his mind and heart, and the sum of that loss of energy and work is so immense that the political prosperity of the nation, almost out of necessity, results in spiritual depletion and fatigue. That in turn causes a further reduction in those cultural outputs that require high concentration and bias. Finally, the author of the Twilight of the Idols asks the following questions: Is it worth it? Is it worth creating an illusory image of a colossus whose greatest achievement seems to be only the fact that other states are afraid of it? Is it worth devoting oneself to delusive benefits, the prosperity of industry and national trade, the things which so far have been the highest value and the most precious wealth of the nation? ${ }^{37}$ Is it worth sacrificing the genius?

\section{The politics of the genius}

Nietzsche's answer, of course, is No. Nothing is worth sacrificing the genius, because the genius is the best realization of humankind's evolutionary potential and the entire purpose of human development.

But can we say more, from Nietzsche's perspective, about the politics of the genius? Suppose that the genius frees himself from the selfeffacing morality of the herd. Suppose that he affirms within himself his own potential for greatness. And suppose that he recognizes the state as a potential tool for realizing his ambitions. What will he do?

Unless we are geniuses ourselves, we cannot say ahead of time what new values the geniuses will create and what particular methods they will use. And even if we ourselves have such genius potential as individuals, every genius is unique; consequently, the actions and creations of one genius will not be predictive of another's. We do not have the

37 Por. F. Nietzsche, Human, All Too Human, p. 242. 
power to decide or even predict the future. Nietzsche suggests that our cultural crisis of values is still in its early stages - "the event itself is far too great, too distant, too remote from the multitude's capacity for comprehension even for the tidings of it to be thought of as having arrived as yet" ${ }^{\prime \prime 3}$ - so we have a long journey ahead of us.

Even so, Nietzsche's "serious goal", as he puts it, is "the cultivation of a new caste that will rule Europe", ${ }^{39}$ and he does give some indication of the broad directions the new masters will take us in as well as the methods they will use.

One indication is that - despite Nietzsche's harsh language in condemning and the Judeo-Christian tradition of slave morality, including its contemporary softer manifestations in democracy and socialism - Nietzsche does not see that tradition as entirely without value. The entire history of mankind, Nietzsche believes, will have prepared the Übermensch for his great creative adventure. In himself the genius of the future will embody the best of the past, including dynamical contributions from the conflicting value systems. The physical vitality and exuberance of the past master types will flow in the genius's blood and sinews. But the Judeo-Christian tradition's emphasis upon internalized, spiritual development will also make its mark: by stressing ruthless self-discipline and self-denial, that tradition has enabled the development of a stronger, more capable type of spirit. The geniuses of the future will thus combine the physical vigor of the aristocratic masters with the spiritual ruthlessness of the slave-priests. In Nietzsche's striking language, the new masters will be "Caesars with the soul of Christ" 40 .

In keeping with Nietzsche's emphasis upon the genius as the embodiment of the best of the past traditions is Nietzsche's suggestion that those traditions manifest themselves within the genius in the form of passions and drives. The source of the genius's new values is instinct, and the genius will find his deepest instinct and let it be a "tyrant". Each individual stands at the end of a long evolutionary line that has built powerful instincts into him, and from that source flow true creativity and true exaltation. The creative source of the future thus lies in instinct, passion, and will. To put the point negatively, the genius will see reason only as a derivative and secondary tool. Reason of course is the tool of modern scientific man, who is one step along the path to the pathetic "last man" ${ }^{41}$. His faith in reason is a crutch; it is an artificial tool of the

38 Idem, The Gay Science, transl. L. Staff, Wydawnictwo Zielona Sowa, Kraków 2003, p. 343.

39 Idem, Beyond Good and Evil, s. 251.

40 Idem, Will to Power, transl. by W. A. Kaufmann and R. J. Hollingdale, Random House, New York 1967, s. 983.

${ }^{41}$ Idem, Thus Spoke Zarathustra, Prologue, s. 5. 
weaker: those who need to feel safe and secure design an orderly world for themselves. By contrast, the creative genius will let his instincts be his legislators - he will let them well up within him, he will nurture them, and he will let them dominate his being. In Nietzsche's words, the "'great man' is great owing to the free play and scope of his desires and to the yet greater power that knows how to press these magnificent monsters into service" ${ }^{\prime \prime 2}$.

Another suggestion that Nietzsche gives us is that the genius will face conflict and exploitation easily, as a fact of life, and he will enter the fray eagerly. The mass of the people, of course, avoid conflict and wish only that life be kind, gentle, and above all safe. Nietzsche dismisses such attitudes contemptuously, as he writes in Beyond Good and Evil:

people now rave everywhere, even under the guise of science, about coming conditions of society in which 'the exploiting character' is to be absent: that sounds to my ear as if they promised to invent a mode of life which should refrain from all organic functions ${ }^{\prime \prime 4}$. So the genius will accept as natural that conflict and exploitation are built into life - and he will school himself be a master of conflict and exploitation. Such men will serve both themselves and the continued evolution of man. "We think that... everything evil, terrible, tyrannical in man, everything in him that is kin to beasts of prey and serpents, serves the enhancement of the species 'man' as much as its opposite does ${ }^{44}$.

Another facet of genius's values, whatever they turn out to be, is an embrace of inequalities. The superman will have no qualms about either his superior abilities or his superior worth to all others. The inferior naturally are fearful and envious of the superior, and their wishful thinking about equal worth of all men are, whether delusional or tactical, has only the effect of retarding human development. About the superior men, Nietzsche proclaims forthrightly: "Their right to exist, the privilege of the full-toned bell over the false and cracked, is a thousand times greater: they alone are our warranty for the future, they alone are liable for the future of man" $^{\prime 45}$. So those who are strong will revel in their superiority and will easily impose their wills upon everyone else, as did the aristocratic masters of part societies.

Every enhancement of the type 'man' has so far been the work of an aristocratic society - and it will be so again and again - a society that belie-

42 Idem, The Will to Power, s. 933.

43 Idem, Beyond Good and Evil. Prelude to a Philosophy of the Future, transl. by

H. Zimmern, T. N. Foulis, Edinburgh and London 1907, s. 259.

44 Ibidem, s. 44.

45 Idem, Genealogy of Morals, Third Essay, s. 14. 
ves in the long order of rank and differences in value between man and man, and that needs slavery in some sense or other ${ }^{46}$.

When it comes to action, the previous three points suggest a further implication. The genius will tap and channel his deepest creative instincts, he will embrace the fact that life is conflict and exploitation, he will accept naturally his own superiority over the masses, and, as a result he will have no problem with using other human beings merely as tools to achieve his ends. Nietzsche phrases the point strongly: "To ordinary human beings, finally - the vast majority who exist for service and the general advantage, and who may exist only for that" $t^{\prime \prime 7}$. The healthy ruling class "accepts with a good conscience the sacrifice of untold human beings, who, for its sake, must be reduced and lowered to incomplete human beings, to slaves, to instruments" 48 . And more ruthlessly: "mankind in the mass sacrificed to the prosperity of a single stronger species of man - that would be an advance" ${ }^{\prime 4}$.

The vocabulary of slavery and war are regular and, given the above, logically consequential features of Nietzsche's writings. A nation that is evolving progressively, he writes, "needs slavery in some sense or other $^{\prime \prime 50}$. Nietzsche is often vague about what sense or other he has in mind, sometimes merely wondering "to what extent a sacrifice of freedom, even enslavement itself, gives the basis for the bringing-forth of a higher type" ${ }^{\prime 51}$. Yet at other times he openly advocates slavery in all forms: "Slavery is, as it seems, both in the cruder and in the more subtle sense, the indispensable means of spiritual discipline and cultivation, too $^{\prime \prime 52}$. Since the vast number of individuals have little-to-no value in themselves, their value-potential can be realized as tools of the mastertypes to bring about species-advancing ends. The same points extend to war. It is one thing to talk generally about conflict and exploitation, but Nietzsche in particular includes war explicitly as a tool in the genius's repertoire of methods to advance culture. War can generate material values for the victor, but Nietzsche gives higher praise to war's psychological value:

I welcome all signs that a more virile, warlike age is about to begin, which will restore honor to courage above all. For this age shall prepare the way for one yet higher, and it shall gather the strength that this higher

\footnotetext{
6 Idem, Beyond Good and Evil, s. 257.

Ibidem, s. 61.

8 Ibid., s. 258.

9 Idem, Genealogy of Morals, Second Essay, s. 12.

Idem, Beyond Good and Evil, s. 257.

1 Idem, The Will to Power, s. 859.

2 Idem, Beyond Good and Evil, s. 190.
} 
age will require one day - the age that will carry heroism into the search for knowledge and that will wage wars for the sake of ideas and their consequences ${ }^{53}$.

For Nietzsche it is not only a historical point that war has elevated mankind, it is a philosophical point that war is necessary to continue to elevate mankind:

War essential. - It is vain rhapsodizing and sentimentality to continue to expect much (even more, to expect a very great deal) from mankind, once it has learned not to wage war. For the time being, we know of no other means to imbue exhausted peoples, as strongly and surely as every great war does, with that raw energy of the battleground, that deep impersonal hatred, that murderous cold-bloodedness with a good conscience, that communal, organized ardor in destroying the enemy, that proud indifference to great losses, to one's own existence and to that of one's friends. That muted, earthquakelike convulsion of the soul ${ }^{54}$.

All of this fits with Nietzsche's self-description as "not by any means 'liberal"' 55 and his contempt for the trade-and-peace liberals of his day: "Our liberal representatives, as is well known, lack the time for reflecting on the nature of man: else they would know that they work in vain when they work for a 'gradual decrease of the military burden'"'56.

\section{Nietzsche, Public Choice, and the future of politics}

A final hint that Nietzsche gives us is worth mentioning. The particular form that European politics takes in the future - whether democratic, republican, aristocratic, or monarchical - will not be significant. The form will not matter because one aspect of the overman's creative political genius will be to find ways to use whatever system he finds himself in to achieve his goals, no matter what its formal structures are.

The politics of our time are formally republican and democratic, and as such Nietzsche scorns them as symptomatic of the weaker, softer, slave values. Yet this raises a puzzle in Nietzsche's account of human cultural development: How could the values of the weaker come to prevail over the values of the stronger? If the powerful really are the powerful, how could the power of politics in contemporary times apparently rest with

53 Idem, The Gay Science, s. 283.

54 Idem, Human, All Too Human, s. 477.

55 Idem, The Gay Science, s. 377.

56 Idem, The Wanderer and His Shadow, s. 284, in: The Portable Nietzsche, ed. and transl. by W. A. Kaufmann, Penguin, New York 1976. 
the masses, the average, and the common? Nietzsche's answer, suggested in The Will to Power, is that "[ $\mathrm{t}]$ he values of the weak prevail because the strong have taken them over as devices of leadership" ${ }^{\prime 57}$. Many strategies are possible in a democracy, and one strategy is to tell voters what they want to hear, knowing that one can get the power one wants from them - but be able to use that power in a way that benefits oneself. For example, if many voters favor a particular welfare benefit, a politician can campaign in favor of that welfare benefit whether he agrees with it or not, knowing that it he will be elected, be able to control the flow of funds, use the program to dispense favors, expand his power constituency, and so on. Translating that into Nietzschean language: savvy will-to-power leaders can use the language of slave morality as a device to maintain or increase their mastery. That can help explain the historical puzzle: "slave" values have the currency that they do in contemporary times because our political masters have learned to manipulate us with a moral code that they use but don't actually believe. As such, Nietzsche could be categorized as a proto-Public-Choice theorist, anticipating developments in political theory two generations after his death ${ }^{58}$. Public Choice analyzes politics on the assumption that politicians are motivated - not by a commitment to the general good or the common welfare - but by self-interested power-seeking. The kind of "self-interest" it typically assumes is zero-sum, describing agents whose actions benefit themselves at the expense of others. Interests conflict, so politics is a battleground of contending agendas, but agendas often couched in lofty, idealistic rhetoric. Public Choice theory is, as Nobel-Prize-winner James Buchanan puts it, "politics without romance".

Yet whether he is a proto-Public-Choice theorist or not, Nietzsche's clear intent is to develop, not a politics without romance, but a politics with romance. His literary-philosophical portrayal of Zarathustra is to be inspirational. Zarathustra will be the creative tyrant. Having mastered himself and others, he will exuberantly and energetically command and realize a magnificent new reality. Zarathustra will lead mankind beyond itself and into an open-ended future. Nietzsche longs for Zarathustra's coming:

But some day, in a stronger age than this decaying, self-doubting present, he must yet come to us, the redeeming man of great love and contempt... This man of the future, who will redeem us not only from the hitherto

57 Idem, The Will to Power, s. 863.

58 Public Choice was first developed academically by James Buchanan and Gordon Tullock in works such as The Calculus of Consent: Logical Foundations of Constitutional Democracy, University of Michigan Press, Ann Arbor 1965) and, a little earlier, philosopher-novelist Ayn Rand portrayed it literarily in Atlas Shrugged, Random House, New York 1957. 
reigning ideal but also from that which was bound to grow out of it, the great nausea, the will to nothingness, nihilism; ...this Antichrist and antinihilist; this victor over God and nothingness - he must come one day ${ }^{59}$.

This romantic streak in Nietzsche's thought, in combination with its ruthless realism, is a powerful combination, and it presents a formidable challenge for liberal-democratic Europe. A Zarathustian politics of genius challenges our deepest assumptions about human nature, the source of values, whether mass values are in conflict with the creation of genius, and whether democracy itself is merely a cover for a new form of aristocratic politics.

59 F. Nietzsche, Genealogy of Morals, Second Essay, s. 24. 